Cad. Líng. Lit. Hebr., n. 15, p. 110-144, 2017

\title{
A INFLUÊNCIA JUDAICA NA LITERATURA DE MOACYR SCLIAR
}

Wremyr Scliar*

\section{Introdução}

Moacyr Scliar nasceu em Porto Alegre em 23 de março de 1937, filho de pais de vieram da Bessarábia, hoje República da Moldávia. ${ }^{1}$

À época, fazia parte da Romênia, e integrava o império czarista russo.

José, o pai de Moacyr, emigrou em 1914 com 7 anos, junto com a mãe Ana, viúva e com 9 filhos. Três filhos já haviam morrido. Todos os filhos e o marido foram acometidos de tifo. $\mathrm{O}$ patriarca, Marcos também morreu da doença na terra natal.

Duas filhas, casadas e com filhos, tinham vindo a Porto Alegre, no ano anterior.

Segundo relato dos parentes, advertidos por um primo francês de que a Grande Guerra era iminente, resolveram emigrar.

Ana desembarcou no Brasil com os outros filhos, um ainda recém-nascido. Destinavam-se à colônia de Quatro Irmãos, município de Erechim, no interior do Rio Grande do Sul, para uma

\footnotetext{
"Wremyr Scliar é professor de direito (PUCRS), doutor, mestre e especialista em direito público. Conselheiro emérito aposentado do Tribunal de Contas (RS). Comenda Oswaldo Vergara - OAB.

${ }^{1}$ Bessarábia era uma região eslava com uma acentuada presença judaica. Pertencia à Romênia na qual habitavam quase meio milhão de judeus. De tempos em tempos, passava do domínio russo ao polonês, deste à Ucrânia, assim como aos otomanos e austro-húngaros.

A família Scliar era da Bessarábia. José, pai do Moacyr, imigra com nacionalidade russa.

Os Slavutzky, seus parentes, viviam na Ucrânia, na fronteira com a Bessarábia. Ana, avó paterna era Slavutzky em solteira, foi casada com um Scliar. Os pais do Moacyr eram primos. As aldeias vizinhas eram Tulchin na Ucrânia e Tomaschpol na Bessarábia, próximas ao rio Dienpr.
} 
fazenda adquirida pela ICA - Yidish Colonization Association ${ }^{2}$, mas face às notícias logo recebidas sobre as dificuldades de adaptação, ficaram em Porto Alegre.

$\mathrm{Na}$ fazenda da colônia da ICA, a atividade era a agricultura. Algo totalmente estranho e proibido aos judeus do império russo. Pelas leis czaristas, somente poderiam habitar em lugares determinados e delimitados, geralmente pequenas aldeias (zonas de residência), não possuir terras, exercer profissões artesanais ou rústicas e sair das aldeias apenas com salvo conduto. Seus impostos eram mais elevados do que os devidos pela cidadania russa. Em períodos de conflito bélico, o serviço militar dos judeus poderia se estender por 15 anos (para os russos, era de 5 anos). Nas aldeias, seguidamente sofriam os ataques dos cossacos, quando seus parcos bens eram pilhados, mulheres estupradas e muitos assassinados. $\mathrm{O}$ ataque mais relembrado era o de Kishinev. A extinção das zonas de residência e a emancipação plena e legal dos judeus, assim como a criminalização do antissemitismo, com pena capital, foi objeto do terceiro decreto firmado por Lenin na revolução socialista de outubro de 1917. Simplesmente abandonaram a zona rural e deslocaram-se para Moscou e Leningrado, filiando-se em massa à revolução, ocupando cargos importantes e ingressando em número excepcional na universidade.

Não haveria condições de, com 9 nove filhos pequenos, Ana, a matriarca, deslocar-se e morar no interior gaúcho. Suas duas filhas já estavam instaladas em Porto Alegre.

Além disso, a colônia era constantemente assaltada e pilhada pelos bandidos que

${ }^{2}$ A ICA, sigla de Yidish Colonization Association, era uma fundação filantrópica europeia que adquiriu duas fazendas no Rio Grande do Sul. Pretendia estimular e ajudar os judeus a imigrarem, abandonando a vida de miséria e distante de uma cada vez mais distante dignidade humana. Em Erechim, adquiriu a área de terras denominada Quatro Irmãos e em Santa Maria, denominada Philipson. Os judeus recebiam passagens de segunda classe para imigrar. Nas fazendas havia agrônomos, escola e professores. Ganhavam uma junta de bois e apoio precário visto que eram regiões de pouca população e parcos de recursos. A destinação econômica era agricultura. Como não sabiam exercer a agricultura, aliás proibidos pela lei czarista, as colônias logo definharam e seus colonos deslocaram-se para as cidades maiores, como Passo Fundo, Santa Maria, Pelotas e Porto Alegre, onde podiam proporcionar estudos ginasiais e ingresso em faculdades para os seus filhos. 
infestavam o interior, onde as comunicações e o policiamento eram precários. Na revolução de 1923, dos gaúchos, Quatro Irmãos sofreu várias pilhagens e ataques.

A mãe de Moacyr, Sara, emigrou com os pais e três irmãos, já no início da década de 20, e vinham de uma região ucraniana, fronteiriça com a Bessarábia. As duas famílias tinham parentesco e mantinham na Europa e depois no Brasil convivência constante.

Do lado materno, a família dirigiu-se para Quatro Irmãos, mas Sara mudou-se para Porto Alegre para estudar; frequentou na Escola Normal Primeiro de Maio, na zona norte, o curso normal (formando-se professora - primeira professora com formação brasileira dos imigrantes.

Retornou a Quatro Irmãos para alfabetizar os filhos dos imigrantes, agora colonos, em bilíngue: em português e yidish. Sara poderia ter ficado em Porto Alegre. Professora era uma profissão valorizada na época. Estaria "prendada" para um futuro de vida mais fácil.

Preferiu voltar a Quatro Irmãos, morar em barracos e cumprir seu compromisso idealístico como professora. Nascida no leste europeu, chegou no colo da mãe no Brasil e foi registrada como nascida no Brasil. Falava e escrevia o português com perfeição.

Também era leitora de autores brasileiros, especialmente José de Alencar, no qual encontrou o nome Moacyr para o filho - do tupi-guarani, que significa filho do sofrimento.

Muitos médicos, engenheiros e outros profissionais liberais da comunidade judaica ainda relembram das suas aulas com nostalgia.

Posteriormente, como a quase totalidade dos colonos, mudaram-se para as cidades principais, onde se dedicaram principalmente ao comércio de roupas ou móveis e matriculando os filhos nas escolas e ginásios locais. 
A origem das duas famílias é portanto no shtetl ${ }^{3}$, palavra que significa pequenas aldeias com predominância de população judaica, situadas em regiões no interior do império russo, com mínimas condições de subsistência. Paralelamente, nas aldeias ou nas grandes cidades os judeus somente habitavam compulsoriamente nos bairros denominados de guettos ${ }^{4}$.

No começo a vida em Porto Alegre era também difícil.

Eles que atravessaram o mundo em busca da "américa" e oportunidades de trabalho e emancipação civil, se depararam com as dificuldades da língua, costumes extremamente diferenciados e um país com resquícios coloniais e economia agropastoril.

É importante destacar que a pequena comunidade judaica que aportou no Rio Grande do Sul inicialmente reinstalou-se com a influência da vida e da cultura das pequenas aldeias, de onde provinham.

Concentraram-se em um bairro pobre ${ }^{5}$, moravam em pequenas casas, geralmente em estilo

${ }^{3}$ Shetl pequenas aldeias de população preponderantemente judaica principalmente na Polônia, Ucrânia, Rússia e Bielorússia e Romênia. Eram zonas obrigatórias para moradia de judeus (zonas de residência).

Não podiam possuir terras nem cultivá-la. Também lhes era vedado ensino superior, empregos públicos. Eram basicamente artesãos - sapateiros, alfaiates, padeiros.

Tinham pequenas escolas de índole religiosa e falavam yidish, um dialeto formado basicamente pelo alemão, russo, polonês e alguns vocábulos em hebraico. O dialeto era grafado em caracteres hebraicos.

Na Polônia, havia 21 jornais diários nesse dialeto, semanários, extensa bibliografia (Shakespeare, clássicos latinos e gregos, Freud, Marx) e duas bibliotecas públicas, além de duas universidades que ensinavam em yidish, grupos teatrais, cantores, corais, indústria cinematográfica, salas de cinema, dois clubes de escritores e até mesmo um partido político que chegou a ter $20 \%$ a $30 \%$ do parlamento.

O yidish ainda é o idioma oficial da República do Birobijan, formada pelo poder soviético para abrigar os judeus que tinham direito ao judaísmo como nacionalidade reconhecida.

${ }^{4}$ Os ghettos, palavra veneziana, era um bairro de residência dos judeus, cercados e vedados aos cristãos. Muitos judeus consideravam-no um local de refúgio, mas na prática era uma prisão urbana. Ali tinham que morar obrigatoriamente.

A França, na revolução do 14 de julho, extinguiu os guettos e posteriormente Napoleão, principalmente na Itália e Alemanha, destruiu todos os muros desses bairros judaicos, declarando a emancipação civil dos judeus.

${ }^{5}$ Os judeus em Porto Alegre concentraram-se no Bom Fim, onde possuíam seu comércio e pequenas indústrias. Ali 
açoriano, com uma porta e uma janela e pequenos pátios.

Moravam todos muito próximos uns aos outros, até mesmo em casas geminadas.

$\mathrm{Na}$ casa de Ana, a avó paterna de Moacyr, fundou-se uma sociedade com finalidades de proteção e amparo. Uma pequena cooperativa que emprestava para aquisição de ferramentas ou mesmo para a sobrevivência nos tempos iniciais. Com a entidade, logo fundaram uma casa de oração e um cemitério.

Seus vizinhos da aldeia e das aldeias próximas que ficaram na Bessarábia possuíam seu endereço, na rua Voluntários da Pátria (a casa, na beira insalubre do rio Guaíba, ainda existe (como poderia alguém morar ali?).

Com a referência do endereço, muitos apareciam de repente, pedindo pousada.

Ana acolhia a todos e os filhos dela cediam as camas com colchões de palha para os imigrantes e dormiam no chão. Só se mudavam quando conseguiam outro local para morar.

Repartiam a comida, usavam a cama e os cobertores (Henrique e depois José - filhos de Ana, fabricaram acolchoados. Henrique, que imigrara com 17 anos, mantivera-se anarquista e quando militantes de esquerda eram presos pela polícia política, ele levava acolchoados para o velho presídio junto à usina, parte submerso no Guaíba, e prestava sua solidariedade aos detidos.

Solidários e fraternos entre si, todos praticavam - modestamente - a ajuda impossível pouca comida e muitas palavras -, que os demais necessitavam.

havia várias sinagogas, casas de oração, colégio. As casas eram simples e pequenas, acanhadas e quase sempre deterioradas.

Diz-se, como anedotário, que no Bom Fim moravam os judeus, por serem pobres. A classe média judaica era denominada de israelitas e morava em Petrópolis, com ruas e casas melhores enquanto que os judeus já enriquecidos, ganharam a pomposa denominação de hebreus, moravam em bairros aristocráticos (Independência e Moinhos de Vento)... 
Falavam yidish entre si e quando já tinham aprendido a língua local, expressavam-se com sotaque peculiar.

Jornais, revistas ou livros eram inicialmente lidos em yidish (quando conseguiam), mas alguns possuíam bibliotecas razoáveis.

Ao dominarem o português, especialmente os filhos, eram leitores vorazes da literatura brasileira e dos autores estrangeiros mais conhecidos.

O ambiente de guetto do Bom Fim se revelava nesse aspecto de solidariedade e vizinhança. A vida era comunitária. As portas e janelas ficavam abertas e as visitas e conversas, ou discussões, era a marca registrada deles.

Edith, a avó materna de Moacyr, por todos chamada de bobe ${ }^{6}$ e que ficou viúva em Porto Alegre, percorria diariamente as ruas do guetto e entrava nas casas, perguntando pelos vizinhos ou parentes. O doente havia melhorado? Os filhos estavam compenetrados no colégio? Já tinham emprego? E as relações familiares?

A bobe sabia sobre o cotidiano de todos. Somente retornava dessas andanças diárias depois de percorrer um bom número de famílias nas suas casas.

Nas noites quentes de verão, sentavam-se nas calçadas, a contar histórias que lembravam das aldeias, as novidades que ouviam no rádio. As calçadas eram parcamente iluminadas pelos poucos postes das ruas, a luz chegava parcialmente às calçadas, prejudicadas pelos galhos e

\footnotetext{
${ }^{6}$ A avó materna de Moacyr chamava-se Edith Slavutzky, casada com um irmão da avó paterna, Ana Slavutzky Scliar. Daí o parentesco.

Por sua figura singular, caridosa e disponível aos que eram necessitados, como doentes, desempregados, situação econômica, era chamada de bobe, palavra que designa avó. Todos, mesmo os não-judeus, nominavam-na de bobe.

Preparava sozinha a ceia de páscoa. Certa vez, cozinhou uma centena de pasteis de uva (um prato da Bessarábia manjar para os judeus. Como seus convidados (a sua família) tardaram, ela comeu tudo sozinha e foi socorrida por um médico.
} 
folhas dos jacarandás do bairro Bom Fim.

A segunda guerra estava em preparação e os judeus que conheciam as tragédias que os civis passavam nas guerras não escondiam sua preocupação. $\mathrm{O}$ assunto era constante.

Quando termina a guerra, o assunto corrente era a luta pela partilha da Pastilha, a independência e a criação do Estado de Israel. As notícias do holocausto ainda não tinham divulgação suficiente, ou credibilidade, para emocioná-los. Isso ocorre logo depois. Os rádios não eram desligados e ouviram-se muitos gritos de alegria quando a partilha foi votada ou declarada a independência de Israel.

No inverno, reuniam-se na sala acanhada das casas.

As paredes necessitando pintura, reboco desgastado, móveis muito simples.

O chá era servido a todos; mantinham o costume da bebida ainda que paulatinamente o chimarrão fosse sendo introduzido entre os judeus do Bom Fim (judeus de bombacha, a indumentária masculina do gaúcho, escreveria mais tarde o Moacyr).

A singeleza das casas não impedia reuniões com muitos participantes. O conforto não fazia falta. Mas o que não faltava nas casas eram livros.

Na casa de Moacyr, uma biblioteca de madeira de pinho sem pintura e apenas aplainada, continha seus primeiros livros em português.

Monteiro Lobato, Viriato Correa, Jorge Amado, Graciliano Ramos, A. J. Cronin, Mark Twain, Tchecov. Mais tarde, Freud, Kafka, Marx e Engels. Mais tarde ainda: Roth, Bashevitz Singer, Bellow.

Moacyr ouvia as histórias contadas nas calçadas ou nas salas atentamente. Seu pai e sua mãe eram exímios contadores de histórias.

José criava suspense nos enredos, muitas vezes interrompia para agregar uma história 
paralela. Narrava lentamente. Como emigrara aos 7 anos (nascido em 1907) não tinha sotaque e falava até mesmo como um gaúcho.

Quando ficava tarde, suspendia a história para continuar no dia seguinte.

Uma foto e uma reportagem de José contando histórias foi publicada na capa de um jornal da década de 80 - sentado em um grupo em torno de uma mesa no bar João do Bom Fim, seus ouvintes estão atentos. Ele, de braços abertos, um sorriso e os óculos de aros escuros.

Qual história estaria contando? Falava emocionado dos filhos: a um deles, se referia como o doutor Nenê e com esse nome (doutor Nenê Scliar) pedia para chamar o filho ao telefone do tribunal onde jurisdicionava.

Sara, professora experiente e que tinha lecionado inclusive no colégio israelita de Porto Alegre, dominava amplamente os seus ouvintes.

Suas histórias continham críticas políticas ou sociais. Claramente definia-se pelas ideias trabalhistas ou socialistas com agudo sendo observativo sobre os fatos que então se desenrolavam no mundo e no país.

Inúmeras vezes, os vizinhos ou amigos traziam para Sara cartas escritas em yidish, cujos destinatários não dominavam a leitura ${ }^{7}$.

Sara lia pausadamente. As cartas tinham muitas folhas em papel leve, escritas com lápis. A leitura nas noites de inverso ou no verão era lenta e encenada.

Ouviam-se pequenos risos, muitos apenas sorriam ou batiam com as mãos nos joelhos

\footnotetext{
${ }^{7}$ As cartas no dialeto yidish usavam caracteres hebraicos. Sara tinha formação profissional para a leitura. Também redigia fluentemente. Como professora alfabetizadora em duas línguas - português e yidish, dominava perfeitamente o ofício. Abandonou o magistério, exercido em Quatro Irmãos e no colégio israelita de Porto Alegre.

Sua pronúncia do yidish era impecável, diziam, com o sotaque do dialeto falado na Rússia, com entonação e palavras diferentes do falado na Polônia e outros países.
} 
ou cabeça, suspiros longos, e não raro o choro entre os ouvintes.

As cartas vinham dos campos de refugiados, dos poucos sobreviventes do holocausto que haviam ficado na Europa ou tinham emigrado para a Palestina. Narravam uma vida difícil, com desemprego, fome, doenças, dificuldades de moradia e seguidamente davam notícias de mortes pela situação precária ou ainda, sobre os mortos nos campos de extermínio. Começaram a circular novas palavras: câmaras de gás, fuzilamentos, Auschwitz.

Pela extrema dramaticidade das cartas, Sara havia tomado uma deliberação: não lia exatamente os textos, amenizando alguns episódios ou lançando esperanças nos ouvintes.

Em realidade, Sara ficcionava parte dos textos, tornando-os menos dramáticos. Era a forma de poupar pessoas idosas e sofridas de mais sofrimento, cujas notícias não lhes trariam ânimo para continuar a vida de adaptação ao novo país.

Esse fato (a ficção na leitura de Sara) o autor ouviu de uma vizinha, muitos anos decorridos. E era citado como uma caridade e apoio de Sara aos parentes que tinham recebido as cartas. Poupava-os, contornando os detalhes, mas deixando antever os fatos reais. Alivia-os de uma dor que seria insuperável. Era a consoladora possível do consolo impossível.

Essa a influência judaica em âmbito familiar recebida por Moacyr.

Ao seu lado, Moacyr tornara-se leitor assíduo de textos que o levariam ao judaísmo. A começar pela Bíblia hebraica, e mais tarde pela literatura já traduzida.

São duas vertentes: a familiar e a cultura judaica.

No entanto, o título desse artigo (lembranças de um irmão mais moço) já mereceria uma explicação.

Moacyr criou-se em ambiente judeu, frequentou a escola primária judaica, militou no movimento sionista de esquerda. Muitos dos seus parentes (tios e primos) exerceram influência 
no mesmo sentido judaico.

A cultura judaica sempre esteve presente na sua formação e com ela conviveu a partir da alfabetização.

Como a formação de uma personalidade naturalmente nascida e desenvolvida judaica, extensa obra literária voltada ao judaísmo, seria Moacyr influenciado pelo judaísmo, apenas? Ou teria sido ele também uma influente personalidade-autor judeu sobre o judaísmo?

Dialeticamente, as duas personalidades conviveram. Moacyr é fruto do judaísmo mas dele não foi um personagem estático: ao contrário, atuou como escritor e como personalidade sobre o judaísmo.

Criado judeu, tem parcela relevante de influência no judaísmo, especialmente na sua literatura.

É o que se pretende comprovar.

Moacyr escritor do judaísmo.

Moacyr Scliar não era religioso. Não adotava os ritos do judaísmo.

Nesse passo, segue as linhas familiares.

Não poucos tios ou primos eram anarquistas, comunistas e em consequência, ateus. Mas isso não os desligava do judaísmo.

As histórias dos Macabeus, Bar-Kochba, os ensinamentos dos profetas, a luta pela justiça e pela liberdade igualdade herdadas do povo milenar estavam presentes nas influências dos familiares de Moacyr.

Depois, da literatura moderna, cujos autores que o impressionavam eram Philiph Roth, Isaac Baschewitz Singer, Isaac Babel, Kafka, além de filósofos como Maimônides (então traduzido) ou cientistas como Freud, Moacyr assimilou ensinamentos que ao longo de suas 
histórias estarão no substrato criativo.

A questão religiosa é relevante.

Foi iniciado judeu. Mas alguns de seus amigos que partilhavam suas ideias não o foram. Também praticou a cerimônia do Bar Mitzvá .

Isso demonstra que não houve ruptura com o judaísmo, por ser alheio ao ritual.

Encontra-se Moacyr no conceito e classificação do Rabino Nilton Bonder na sua monografia Carta aos Judeus ${ }^{9}$ :

Gênesis

O judaísmo não é uma religião. O patrimônio coletivo dos judeus não é uma religião.

Nas origens o judaísmo não apresenta ideias de salvação ou iluminação pessoal. Abraão é um visionário de um novo senso coletivo para "suas sementes numerosas" e que parte em busca de uma nova terra. Essa terra não tem características de um território ou de um estado, visto que não há descrição ou demarcação do mesmo - é apenas uma terra que será "mostrada". O significado maior deste "chão" é uma nova plataforma, uma nova forma de vínculo.

Nesse solo, diz Bonder, se produziria a solidariedade e a integridade, uma relação inédita proposta pela Bíblia.

O pilar principal é o coletivo de Israel. A temática não é teológica, mas a capacidade de organizar-se como família e tribo.

Ao contrário dos gregos e dos romanos, os judeus não percebiam o instituto político estatal, exceto como organização pragmática e solidária.

${ }^{8}$ Bar Mitzvá, filho do compromisso. É a cerimônia de emancipação dos jovens judeus - meninos e meninas - aos 13 anos. Bar é aramaico enquanto que Mitzvá soa como hebreu.

${ }^{9}$ Rabino Nilton Bonder é gaúcho e fez sua formação em N. York, onde também concluiu o curso de engenharia.

Carta aos Judeus é uma monografia cuja primeira edição foi impressa pela Congregação Judaica do Brasil, em maio de 2014, no Rio de Janeiro. O texto referenciado inicia a monografia. 
Se não foi a religião, o que conduziu Moacyr?

Sem dúvida, a influência familiar e a cultura judaica. Um conjunto ético e solidarista.

E sobre essa cultura judaica, repisa-se. Moacyr fez incidir sua própria criatividade criada pelo judaísmo.

É uma contradição dialética, da qual nasceu um escritor e sua obra.

\section{A influência familiar}

Moacyr Scliar é filho e pupilo de Sara Scliar.

O pai, José, era um obreiro, empregado em uma indústria familiar, que depois forma um pequeno negócio que jamais teve sucesso econômico.

Foi aluno no ensino fundamental, aluno da própria mãe, na escola israelita (Escola de Educação e Cultura), formada por dois prédios antigos, pintados de amarelo, e situados na Av. Oswaldo Aranha, na parte extrema no bairro Bom Fim.

O nome da avenida é uma feliz coincidência. Aranha era um fazendeiro da fronteira do Rio Grande do Sul. Portanto, um tipo atávico, cavaleiro ligado ao campo, ao gado, ao cavalo. Suas roupas e hábitos alimentares, como gaúcho, eram diferenciados e estranhos aos demais brasileiros

Estudou na Europa e torna-se íntimo e conselheiro de Getúlio Vargas, na linha de frente da revolução de 1930.

Vitoriosa a revolução, a avenida ganha seu nome.

Em 1947, iria presidir - já como experiente diplomata e a convite da própria ONU, a assembleia que partilhou a Palestina e permitiu a criação do Estado de Israel. 
A presidência da sessão que partilha da Palestina por Oswaldo Aranha é memorável, não apenas pelo resultado, mas também por outro aspecto.

Aranha conduz as várias reuniões, suspendendo propositadamente algumas, até que o quórum favorável se confirmasse.

Como caudilho e diplomata (fora embaixador nos Estados Unidos, capa como destaque da revista Time), sem Aranha, o gaúcho e brasileiro, a partilha não teria sido votada favoravelmente,

Com mão e voz firme, martelo de madeira na mãe (segurava o relho com que conduzia o cavalo?) Aranha, que lutara denodadamente os combates de outubro de 1930, tomando o quartel federal em Porto Alegre, batia seu martelo, símbolo do poder, gritando "order" e impedindo as dissidências.

Ao final, como no campo de batalha, expressou: todos entenderam, digam apenas sim ou não à partilha. Nada mais.

A partilha aprovada, deu uma comovida entrevista na qual declarou sua parcialidade pelo resultado favorável e pelo qual lutou como se estivesse em uma trincheira.

A escola judaica não poderia ficar em logradouro com nome mais adequado.

A mãe era rigorosa no acompanhamento do aluno Moacyr.

Já no ginásio, cursava o Colégio Rosário, de orientação e direção marista, um educandário reconhecido por sua severidade e exigência, com uniformes em estilo militar. Moacyr, na conclusão da primeira série, em uniforme de gala branco e quepe com detalhes pretos e dourados, foi chamado inúmeras vezes pelo reitor na cerimônia de fim de ano: ganhou todas as medalhas oferecidas aos alunos: religião, matemática, português, latim, filosofia.

Desse colégio, Moacyr assimilou uma disciplina rígida e produtiva para o trabalho: para a 
criação literária e para a vida profissional de médico sanitarista.

Juntado o ensino formal aos conceitos éticos judaicos, estava formado o cidadão e humanista exemplar.

Nessa mesma época Moacyr estudou violino com um professor da sinfônica. Durou pouco, cerca de um a dois anos.

Mas da janela da casa - sempre aberta -, ouviam-se seus sons conduzidos por mãos e ouvidos privilegiados.

Tocava facilmente Hatikva, o hino adotado de Israel.

Seu compositor preferido, talvez a partir dessas aulas, foi Mozart, embora apreciasse Bach e jazz.

No ano seguinte, a mãe determinou aos filhos que fizessem uma redação por dia. Às dezessete horas, diariamente, avisou, iria corrigir. E iniciava a correção afirmando: redação inicia com uma ideia na cabeça. depois vem o papel e o texto tem início, meio e fim. Os temas: meus professores, pôr do sol no Guaíba, as árvores da minha rua. Outros dias, o tema era livre.

Concluído o ano, e 300 redações produzidas, Moacyr pediu uma folga: "Pô mãe, agora vem as férias". Ela reagiu imediatamente: não tem férias, serão duas redações por dia.

Moacyr que tinha concluído o primeiro ano de latim (Ludus Primus, do Padre Miltom Valente), não se intimidou: fez sessenta redações em latim.

Sara economizava nas suas roupas, o que sobrava em dinheiro revertia em livros. Mensalmente ela voltava da Livraria do Globo com pilhas de livros.

Faltavam móveis na casa, as panelas estavam gastas, o fogão ainda era à lenha: não faltavam livros.

Quando o irmão de Moacyr recebeu um prêmio considerável em dinheiro em um programa 
de rádio (Farroupilha), respondendo sobre o compositor polonês Paderewski, pediu à mãe para ganhar uma bicicleta. Até hoje espera. Ganhou dezenas de livros comprados imediatamente na mesma livraria.

Sara logo se apercebeu do talento de Moacyr. Seus professores leigos ou padres, do primário ao ginásio, falaram sobre esse talento para ela. Falaram da criatividade de Moacyr, com orgulho até o final de suas vidas. Ela indagava sempre aos mestres sobre seu aproveitamento. Eles eram unânimes em recomendar o estímulo contínuo ao talento de Moacyr.

Não apenas em português, mas em todas as matérias.

Com uma redação na mão e Moacyr na outra, subiu ao alto Petrópolis (bairro de classe média alta) e procurou a casa de Érico Veríssimo. Ele mesmo atendeu à porta.

Disse: gostaria que o senhor lesse essa redação do meu filho. Érico pediu para deixar com ele e voltassem depois. Agora, disse Sara.

Érico pediu uns minutos e voltou, explicando: ele deve ler bastante e escrever sempre.

Já na volta, Moacyr percebeu que levaram um texto incompleto. Érico não se apercebeu....

Na família, o tio Henrique, pai do pintor Carlos Scliar, foi influência importante para o pequeno Moacyr. Sua biblioteca era imensa. Lia sobretudo autores anarquistas, como a Enciclopédia de Elie Reclus ${ }^{10}$.

Seus muitos quadros, inclusive do filho, eram as telas clássicas a óleo da década de 40. Carlos também influenciou Moacyr. Já era um pintor consagrado que recomendava viajar e

\footnotetext{
${ }^{10}$ Elie Reclus foi um francês intelectual anarquista, que escreveu uma enciclopédia, muito popular na França. Durante a comuna de Paris, ele foi diretor da biblioteca nacional. É ícone do pensamento anarquista. Henrique Scliar possuía a edição completa e lia, como hábito de consulta, constantemente seus verbetes.
} 
conhecer pessoas. Ele próprio ex-combatente voluntário na II Guerra e aluno do Belas Artes de Paris. Dizia: “é preferível ser pobre em Paris do que rico em Porto Alegre”.

Carlos concluiu em Paris o Belas Artes, cujos ensinamentos se somaram à extraordinária e inesperada oportunidade que o marechal Mascarenhas de Moraes lhe proporcionara como cabo de comunicações e artilheiro da Força Expedicionária Brasileira em Florença de conhecer, sozinho e em caráter privilegiado, a Galeria Uffizzi e depois em Milão visitar o pintor Morandi, apresentado por um famoso colecionador, que lhe ofertou um peça de madeira e metal do século XVI, Após Paris, onde ficou em 1948 e 1952, Carlos viajou pelo leste europeu; através do trem transiberiano foi aos confins da Ásia. Conheceu Picasso em Varsóvia com quem pintou cartazes pela paz durante um festival pelo pacifismo e contra a ameaça de guerra.

Os fatos foram contados por Carlos no seu retorno, em almoço dominical de frango assado e massa na casa dos pais do Moacyr.

Tempos depois o autor entrou no Hotel Saint Michel, onde Carlos se hospedara em Paris, no Amado e Zélia Gattai. Em um domingo, Carlos conduziu a ambos ao castelo perto de Paris onde morava o pintor Chagall e o russo, já famoso, os recebeu para uma visita.

Henrique possuía uma chácara próxima de Porto Alegre. Nela, no verão, Moacyr conheceu Jorge e Zélia, que narra o fato nas suas memórias ${ }^{11}$.

Pablo Neruda, Heitor Villalobos, Samuel Vainer (então escondido no sítio em 1954)

\footnotetext{
${ }^{11}$ Quando frequentavam a chácara de Henrique Scliar, no vizinho município de Viamão, próximo a Porto Alegre, Zélia e Jorge já tinham voltado do exílio na Tchecoslováquia e França. Em Paris, se tornaram amigos de Carlos, o pintor filho de Henrique. Moraram no mesmo hotel e muitas vezes faziam refeições preparadas pelo pintor no seu quarto.

Carlos os acolheu e proporcionou seus já adiantados conhecimentos sobre a Europa ao deputado federal constituinte cassado (em 1947) e sua esposa. Moacyr, garoto, era objeto de curiosidade e carinho do casal. Muito depois, ficaram amigos e o escritor gaúcho visitou-os no bairro Casa Amarela, em Salvador.
} 
também eram hóspedes constantes da chácara do velho tio Henrique, e foram alvo do interesse do menino Moacyr.

Seu primo Salomão fez a primeira longa metragem gaúcho: Vento Norte.

Leonar Scliar Cabral, prima, é filóloga renomada e autora de muitas obras.

Esther, prima, professora e compositora de música. Lecionava na Escola Nacional de Música e muitos compositores (Carlos Lyra, Camargo Mariani, entre outros, passaram pelas suas aulas).

Todos parentes de parte de pai, tinham características peculiares que influenciaram o menino Moacyr. José tinha um irmão (o caçula) em Curitiba, que citava poemas de Shakespeare de memória e assistia temporadas de ópera em Nova York. Com esse tio, Manoel, Moacyr conversava longamente, caminhando pelas calçadas nas noites de Porto Alegre.

Algumas tias, já idosas, colavam cartazes pela paz, pão e terra nos muros durante as madrugadas de Porto Alegre

De parte da mãe, o primo Oscar (Chico), que depois foi "masquir" (dirigente em hebraico) do kibutz Bror Chail, Israel, apresentou a teoria sionista e o tio, irmão de Sara, o mais jovem Solon, era articulado, precocemente formado em economia (raro entre os judeus) e com ideias socialistas avançadas.

Duas personagens, são destacadas nessa influência familiar: as avós.

A bobe, materna, e Ana, a paterna.

A bobe era extrovertida, ligada à comunidade.

Ana, raramente falava. Tinha esquecido o yidish e não aprendera português. Vivia calada e observando os parentes e vizinhos. No que pensaria? Tinha a façanha de convencer um motorneiro de bonde, em cuja linha embarcara por engano, para desviar do trajeto e seguir até a 
frente da sua casa. Ninguém jamais entendeu em que língua conversou com o motorneiro.

Sua liderança silenciosa na família e na comunidade marcou Moacyr.

Foi sua a sua trajetória heroica, sacrificante, única: de manter como mãe viúva nove filhos, em meio ao tifo, à pobreza, zona infestada e insalubre à beira do rio Guaíba. Somente o filho mais novo, Manoel, estudou: engenharia, matemática e agronomia. Esse, ainda garoto, alfabetizou todos os irmãos na nova língua da nova terra.

\section{A influência cultural}

Debruçado constantemente em leituras (durante as refeições, nos bondes) e no ofício de escritor, ambas as atividades nascem no seio da família.

Seu personagem, Capitão Birobidjan, cujo nome era Mayer Guinzburg, é inspirado no seu tio Henrique.

O livro, ainda na juventude do escritor, $O$ exército de Um Homem $S o^{12}$, tornou-se emblemático na produção do Moacyr.

Um anarquista que solitariamente toma um casarão antigo e junto com os animais domésticos, forma um kolkhós ${ }^{13}$.

O local da casa, numa estrada que se denominava Beco do Salso, era o caminho em direção à Viamão, onde ficava a chácara do tio Henrique Scliar. Não é coincidência. O ambiente do

${ }^{12}$ O Exército de Um Homem Só é um emblemático livro da fase inicial de Moacyr.

Frequentemente é citado como sinônimo da literatura scliariana.

${ }^{13}$ Kolkhós, literalmente fazenda coletiva, que seria a base da produção agrícola soviética. Sua irmã gêmea são os kibutzim ou kibutz no singular, também como fazendas coletivas em Israel.

Fracassaram por distintos fatores mas foram criadas para solver o problema agrário tanto social como econômico e combater os camponeses ricos (os kulaks) que se recusavam a colaborar com a revolução socialista. 
sítio, inclusive, a moradia e a famosa piscina de água corrente e gelada, onde aos domingos de verão, se reunia a família, convidados e muitos intelectuais e artistas, é o embrião do Clube de Cultura $^{14}$ fundado por um grupo liderado pelo tio, pai do Carlos.

O Clube de Cultura é um clube judaico de Porto Alegre, laico e de orientação progressista, cujas atividades marcavam os momentos culminantes do povo judeu (como o levante do guetto de Varsóvia, de 19 de abril de 1943).

Nesse clube, cujo auditório tem o nome do seu tio Henrique, Moacyr, ainda estudante de medicina, promoveu no final da década de 50, uma sequência de conferências com os principais psicanalistas gaúchos, então um centro pioneiro nessa especialidade.

Noite após noite, o auditório ficava lotado de médicos, curiosos, pacientes e estudantes. O fato marcou a cena médica local e desvendou ao público e à imprensa os m então meandros ocultos da psicanálise desenvolvida por Freud.

Sob a influência cultural do ideário socialista, objetivo do engajamento de muitos judeus na causa proletária, Moacyr vai buscar sua primeira inspiração autêntica, próxima à fonte da narrativa, na própria família. É o Capitão.

Aos filósofos, cientistas, escritores, pensadores e liderança política entre os judeus, Moacyr Scliar refere-se explicitamente e com arguta observação em sua obra $A$ condição judaica ${ }^{15}$.

\footnotetext{
${ }^{14}$ O Clube de Cultura situa-se no bairro Bom Fim, em Porto Alegre. Idealizado e fundado em 1950 sob a liderança de Henrique Scliar, substituiu a velha casa da rua Ramiro Barcelos por modernas instalações. A geração fundadora é toda falecida.

Seus espetáculos de teatro, orquestra sinfônica, conferências, poesia e a orientação progressista afinada com as questões nacionais e com o povo brasileiro, registrou um período de efetiva e exitosa participação política. Oradores de renome, intelectuais, políticos, escritores lá estiveram, também lotando seu auditório.

${ }^{15}$ Em $A$ condição judaica, um pequeno ensaio sobre o judaísmo, no qual Moacyr, no subtítulo, resume desde logo o objeto da obra. A sua intenção: Das tábuas da lei à mesa da cozinha. Praticamente uma autobiografia, com intensa emoção e confissões do escritor e médico sobre sua vida pessoal, influências, utopias e claro: o fundo judaico.
}

Com clareza, mostra as suas várias fases políticas. As primeiras leituras, o engajamento intelectual, a decepção com 
Relembra a trajetória de Karl Marx, Walter Benjamin e Sigmund Freud.

Todos judeus. Todos escreviam em alemão. Todos foram revolucionários.

Não esquece de Franz Kafka e coloca Albert Einstein ao lado de Freud e Marx.

Quando se refere à revolução russa de 1917, Scliar não olvida da figura de Leon Trotzky e dos revolucionários como Litvinov, Kaganovicht, Sverdlov, Rosa Luxemburog e traz à lembrança o poeta Ossip Mandelstam.

De Trotzky, não apenas a obra revolucionária e sua morte trágica afetaram Scliar. Pensaria nele como um profeta? Profeta desarmado?

Marx, para Scliar, também era profeta? Armado ou desarmado?

Qual o possível (ou impossível) alinhamento de Moacyr Scliar com a filosofia marxista?

Em primeiro plano, a solidariedade com os proletários, aos quais dedicou também sua profissão como médico sanitarista, atuando na área de planejamento (doutor pela universidade fluminense em saúde pública e pós-graduado em Israel em medicina comunitária).

Em segundo lugar, a teoria da emancipação do homem e a sua desalienação. Nesse aspecto, citava Marx em Die Judenfrage (A questão judaica) agregando que o filósofo revolucionário concluía com uma frase famosa: "A emancipação do judeu é e a emancipação da sociedade do judaísmo".

Embora não fosse um militante político, após desistir do engajamento com o sionismo de esquerda, Moacyr Scliar assimilou do marxismo o que ele possui de inovador e revolucionário: a realidade dos oprimidos da terra conflita com os mais antigos ensinamentos legados pelos o regime soviético e por fim seu declarado apego à humanidade e aos seres humanos.

Declara-se um utópico diferente: o utópico otimista pela convicção profissional, como médico sanitarista e como escritor. 
hebreus na sua Bíblia, na cultura judaica milenar e sobretudo nas figuras e nos discursos dos profetas.

Não poucas vezes, contudo, Scliar demonstrava aversão pelo personalismo e pelos erros cometidos pela União Soviética. Utilizava expressões candentes em relação aos erros históricos dos militantes da extrema esquerda.

Inconfundível essa crítica severa com a sua leitura da teoria marxista.

Nela entendia o escritor haver princípios filosóficos aos quais estava filiado inexoravelmente, como judeu e como cidadão do mundo.

Em um depósito (um pequeno galpão) no pátio da sua casa paterna, Moacyr possuía muitas prateleiras de livros marxistas (melhor mantê-los longe dos olhos estranhos, afinal eram proibidos).

Eram as obras de Marx, Engels, Plekhanov, Boroshov (um judeu marxista). Todos em edições populares, brochuras simples, com capas e folhas já gastas de tanto manuseio do Moacyr. A maioria impressos pelo editorial Progresso, que desde Moscou editava na língua portuguesa, afinada com Portugal.

Lia, anotando e sublinhando, como lições que o adolescente vai levar para a vida futura e que não deveriam ser esquecidas.

Em uma entrevista ${ }^{16}$ no primeiro capítulo de coletânea de artigos de vários críticos (Moacyr

\footnotetext{
16 Trata-se de uma entrevista de Moacyr que abre a leitura de uma coletânea de artigos e ensaios de críticos e autores literários.

Não por acaso, é o primeiro capítulo do livro.

No texto, Moacyr faz uma autoanálise da sua ideologia política, traçando uma cronologia que inicia com a adolescência e prossegue até a sua maturidade.

Não se desfaz do seu ideário, mas como muitos de sua geração, declara sua decepção com o socialismo real e os fatos ocorridos na União Soviética.
} 
Scliar, a escrita de um homem só) - título sumamente sugestivo, ligado (inconsciente ou consciente - uma ligação orgânico-afetiva?) ao seu livro $O$ exército de um homem só, cujo personagem é um idealista que almeja uma sociedade sem classes (Moacyr era um único soldado?), ele define sua ideologia filosofia política com clareza:

Cansei de sofrer. Na minha família havia muita gente de esquerda.

Não o meu pai, que era politicamente anódino, um homem que não tinha abertura nem preocupações sociais.

Mas eu tinha tios muito cultos, que eram de esquerda, e muito cedo fui pelo mesmo caminho. Nunca cheguei a ser um ativista.

Muitos jovens do Bom Fim foram presos. Não foi o meu caso, mas eu tinha uma cultura política muito grande.

Li Marx e, principalmente, Engels.

O que mais me fascinava é que esses autores apresentavam um modelo para compreender o mundo que era absolutamente lógico e matemático.

Era uma coisa de dividir oprimidos e opressores, burguesia e proletariado, o mal e o bem.

Um país era o símbolo do bem, a União Soviética, e um país era o símbolo do mal, os Estados Unidos.

Durante a minha juventude esse esquema foi muito satisfatório, dava respostas absolutamente tranquilizantes sobre o que tínhamos que pensar a respeito do mundo.

Mas isso desabou a partir daí, fui perdendo minhas convicções em termos de política e toda a minha geração sofreu esse desencanto.

Não chega a ser um desencanto do mundo como falava Max Weber, mas é um desencanto em relação à capacidade da política resolver os problemas do mundo.

Por outro lado, fui compreendendo cada vez mais as pessoas, me preocupando muito com as coisas que fazem as pessoas sofrerem. Não digo que não deva haver militância política, digo que não sou uma pessoa para isso.

Compreender o ser humano é uma coisa importante, mesmo porque não temos outra alternativa.

A verdade é que os seres humanos são criaturas muito desamparadas que. eventualmente, se mostram capazes de coisas admiráveis.

Eu não sou pessimista em relação à espécie humana.

Muitos escritores da minha geração discordam.

Não é o meu ponto de vista. E também não é o meu ponto de vista que a humanidade ou mesmo que o Brasil estejam perdidos.

Não é verdade.

Tenho uma clara convicção de que, ao longo da minha vida, vi o mundo e o país melhorarem. ${ }^{17}$

É importante como relato de um testemunho em causa própria, com a coragem de dizer e enfrentar os fatos.

${ }^{17}$ Os antigos hebreus proibiam a escravidão entre seu povo. Casa homem era considerado um igual (irmãos entre todos). 
Cad. Líng. Lit. Hebr., n. 15, p. 110-144, 2017

O “desabou” mencionado por Moacyr são as revelações do vigésimo congresso do PCURSS, quando foram trazidos à tona e ao conhecimento do mundo os crimes cometidos por Stalin.

O que desaba para Moacyr não é a teoria da alienação, a dialética, ou a infraestrutura e superestrutura descobertas por Marx, nem a origem da família, da propriedade privada e do estado, de Engels.

O que desaba é a violência de estado revelada: o conflito do homem com a máquina estatal, a eterna busca da liberdade e da igualdade. Essa negatividade do ser humano afeta Moacyr. Daí o predicado desabar.

Duas observações sobre a militância de Moacyr Scliar acima referida.

Ao se formar em medicina, na universidade federal, em 1962, foi orador da turma.

No discurso, tenso e ouvido em absoluto silêncio, parafraseia Ferreira Gullar ("Morrem quatro por minuto na América Latina de fome").

E clamou por uma medicina social, engajada, voltada para os pobres, sem interesses econômicos exploratórios.

Quando concluiu, o diretor da faculdade, com a pose de um senador do império romano, quebrando o protocolo, retomou a palavra e lançou seu repúdio ao idealismo e às utopias da juventude que o Moacyr acabara de expor, representando o pensamento dos estudantes em plena crise da guerra fria.

Nenhum povo antigo, e mesmo na modernidade, adotou esse princípio.

Mesmo os escravos participavam da família, praticavam seus ritos e havia normas que impunham o respeito pela integridade e pelo corpo, respeitado como homem e como trabalhador. A surpresa manifestada por Ambrogio Donini é relevante, pela importância, desse autor italiano para a história das religiões. 
Indagou, ácida e preconceituosamente, o diretor: “Onde, jovem, está essa Canaã prometida?".

Pouco depois, já durante os anos de chumbo, ao realizar uma prova de concurso público, Moacyr foi retirado da sala. Estava vetada, naquelas circunstâncias de chumbo, seu ingresso no serviço público.

Quanto à referência ao pai, modesto empresário, não possuía o curso primário completo. Entretanto, tinha um razoável senso pragmático, e como a mãe do Moacyr, distinguia perfeitamente o que era retrógrado e deveria ser superado na sociedade, e se manifestava firmemente sobre as necessidades dos operários e necessitados.

Quanto a Friedrich Engels, citado - em depoimento -, como sua leitura revolucionária principal, estaria se referindo ao $A$ origem da família, da propriedade e do estado, pequena brochura em edição popular que Moacyr possuía, junto com o Manifesto e outras obras.

Da Bíblia hebraica assimilou a natureza mais íntima do Êxodo e do Deuteronômio: é afirmar a liberdade (a escravidão não era admitida entre os hebreus).

A proibição da escravidão surpreendeu um historiador marxista, que a revela entusiasmado. Ambrogio Donini afirma que nenhum povo da antiguidade, exceto os judeus, proibiram a escravidão entre seus irmãos.

A outra natureza é a declaração da igualdade entre os judeus, além do respeito aos direitos do estrangeiro, das mulheres, crianças, órfãos e obrigação de proteção e caridade com os pobres (dízimo, canto da terra), o ano jubilar, a lei como instrumento de justiça.

Pode-se acrescer, sem nenhuma margem de erro, que os hebreus praticaram a república e a democracia muitos séculos antes dos romanos e gregos e o primado da lei tinha por finalidade 
maior a concretização da justiça ${ }^{18}$.

Esse legado é entronizado por Moacyr na sua obra e são muitos os claros exemplos dessa singular adesão ao judaísmo: Os vendilhões do templo; A mulher que escreveu a Bíblia, Manual da paixão solitária, além de contos e crônicas.

Está presente na obra de Moacyr não o respeito por uma cultura antiga da qual é legatário; mas a sua compreensão e adaptação aos tempos atuais assim como à sua própria estrutura literária.

Não são elogios aos textos antigos, mas o aproveitamento inspirador com muita dose de humor judaico.

A partir da tese da Harold Bloom, segundo a qual os textos atribuídos ao rei Salomão tinham um notável estilo feminino ${ }^{19}$, Moacyr se vale da novidade do crítico americano para inferir a sua própria criatividade. De quem era a mão feminina que escrevia por Salomão?

A narrativa foge completamente ao cânone bíblico e sagrado, rompe o ritual, afronta (?) a ortodoxia.

Certamente, Moacyr estava sorridente ou rindo enquanto sua narrativa ganhava a letra

\footnotetext{
${ }^{18}$ A leitura dos textos bíblicos hebreus revela o primado da lei, a lei como função de justiça e valores civilizatórios como a democracia e a república, além de uma incisiva proteção e assistência social. Eles são notáveis entre os profetas, especialmente Isaías (em realidade três profetas tiveram o mesmo nome. O Isaías reconhecido é o terceiro deles. Atuavam como os modernos fiscais da lei, reclamando o seu cumprimento, ou a falsidade dos atos que simulavam o cumprimento da lei.

Não eram magos ou adivinhos, nem alinhados com magias. Viviam a mais intensa realidade com visão política, social e econômica dos fatos que se desenrolavam em sua época. Sua crítica social se dirigia aos membros da elite e também aos homens comuns.

${ }^{19}$ Harold Bloom lança a tese de que o texto salomônico seria obra feminina.

Para Scliar, é o suficiente uma pequena folha para construir um bosque.

Sua criatividade não é limitada por ideias discutíveis. Ele procura no prazer da escrita encontrar o leitor e transmitirlhe a alegria da leitura.
} 
impressa. Zombaria? Não, apenas o livre e independente ato de criação.

Um símbolo autenticamente milenar e judaico.

No Vendilhões do Templo, novamente o mesmo processo criativo. $\mathrm{O}$ episódio bíblico critica acidamente a prática de venda de moedas que os cambistas exerciam nas portas do templo de Jerusalém, Moacyr também monta uma narrativa que no fundo é igualmente crítica.

A esses acresce-se o Manual da paixão solitária.

Nessas três obras, como Marx, Moacyr põe o judaísmo sobre seus próprios pés e como um intérprete dos livros sagrados, reescreve a sua leitura bíblica.

Das leituras bíblicas, Moacyr Scliar expressa até mesmo uma certa alegria com os textos dos profetas.

Refere-se especialmente a Jeremias é Isaías. Vale transcrever um dos preferidos de Moacyr, o profeta Isaías, cujos discursos e críticas aos poderosos se orientavam pelo pacifismo e a paz:

\section{4}

E julgará entre as gentes, e repreenderá a muitos povos; e converterão as suas espadas em enxadões e as lanças em foices; não alçará espada nação contra nação, nem aprenderão mais a guerrear.

A vertente é extensa.

A Moacyr não passaria jamais incólume nas suas constantes leituras bíblicas (um manancial de histórias e ensinamentos) que a república e a democracia entre os hebreus foram praticadas centenas de anos anteriores à democracia da Ágora ateniense (paliá agorá, velho mercado em grego) e à república romana.

Do texto testamentário hebreu, Deuteronômio, no qual Moacyr tantas e tantas vezes leu e refletiu, se transcreve: 
17.14. Quando entrares na terra, que te dá o Senhor teu Deus, e a possuíres, e nela habitares, e disseres: Porei sobre mim um rei, assim como têm todas as gentes que estão ao redor de mim:

17.15. Porás certamente sobre como rei aquele que escolher o Senhor teu Deus: dentre teus irmãos porás rei sobre ti: não poderás pôr homem estranho sobre ti, que não seja de teus irmãos.

17.16. Porém não multiplicará para si cavalos, nem fará voltar o povo ao Edito, para multiplicar cavalos; pois o Senhor vos tem dito: Nunca mais voltareis por este caminho.

17.17. Tão pouco para si multiplicará mulheres, para que seu coração se não desvie: nem prata nem outo multiplicará muito para si.

17.18. Será também que, quando se assentar sobre o trono do seu reino, então escreverá para si um traslado desta lei num livro, do que está diante dos sacerdotes levitas.

17.19. E o terá consigo, e nele lerá todos os dias da sua vida; para que aprenda a temer ao Senhor seu Deus, para guardar todas as palavras desta lei, e estes estatutos para fazê-los;

17.20. Para que o seu coração não se levante sobre os seus irmãos, e não se aparte do mandamento, nem para a direita nem para a esquerda: para que prolongue os dias no seu reino, ele e seus filhos no meio de Israel.

Aqui estão preconizados e inscritos os princípios: (a) democrático: porque o povo ainda não tem rei, mas tem o poder de escolher um, desde que seja entre seus irmãos (igualdade e escolha): (b) republicano: porque o rei rigorosamente cumprirá a lei que já está outorgada e a dela será serviente cumpridor.

Ainda se configuram princípios como o da probidade (riqueza, mulheres, cavalos) e o da legalidade (copiar e manter a lei, observando-a sempre.

Moacyr apreendeu. Não em ritual místico ou religioso. Mas como um fundamento políticoinstitucional cujo objeto é o direito humano inalienável.

Essa segunda vertente, a cultura judaica, haurida no âmbito familiar e compilada por intensa leitura e reflexão cultural, pode ser conceituada em termos mais amplos, como o 
humanismo de Moacyr Scliar.

É judaico esse humanismo?

Sim. Mas universal ao mesmo tempo.

Não apenas dos pensadores, revolucionários e escritores judeus Moacyr buscou as bases fundamentais desse humanismo.

Pelo menos duas fontes lhe são caras: Anton Tchecov e Mark Twain, que considerava como dois maiores, se não os maiores dos contistas; russo e americano que o entusiasmam e influenciam.

E a outra, o pensamento iluminista que a partir da revolução francesa introduz a noção e o conceito legal de cidadão e a tríplice declaração de liberdade, igualdade e fraternidade, resultando na emancipação dos judeus na França e após em boa parte da Europa.

Sem dedicar-se às ciências jurídicas, Moacyr incursiona em campos que poderiam estar alheios aos seus conhecimentos. Mas não consegue apaziguar sua criatividade e em uma peça única e sumamente original, analisa o artigo 15 da Carta da Organização das Nações Unidas.

O texto integra um livro sobre direitos humanos, publicado sob os auspícios da ONU em colaboração (em português) com o governo brasileiro. Trata-se de Direitos humanos no $\operatorname{cotidiano}^{20}$.

\footnotetext{
${ }^{20}$ Moacyr Scliar não tinha ligações profundas, por óbvio, com a ciência jurídica.

Mas como intelectual, não lhe faltava o conteúdo humanístico, como na frase de Lucrécio, o filósofo latino seguidor do grego Epicuro: nada do que é humano me é estranho.

Suas duas incursões, sobre cidadania e sobre nacionalidade tem o enfoque da afirmação, concretização, ampliação e proteção dos direitos humanos.

Vale-se de dois contos, duas histórias. Chega ao âmago mais profundo das duas questões institucionais, complexamente jurídicas, pela literatura.

Um intelectual que não rejeita desafios, encontrando em seu ofício de escritor, como intelectual completo, os meios para deslindá-los.
} 
Cad. Líng. Lit. Hebr., n. 15, p. 110-144, 2017

O dispositivo refere-se ao direito ao instituto da nacionalidade, no mais profundo mergulho sobre os direitos humanos que serão afirmados pelas nações que derrotaram o nazismo e o fascismo.

No texto Moacyr, com muita emoção e consciência histórica, agrega a experiência trágica do povo hebreu que vagou pela terra ao ideal esculpido soberbamente na Carta Universal, cujas cláusulas, notadamente a igualdade e os direitos humanos ali descritos, inspiram-se tranquilamente na Torá.

Escreve Moacyr:

Descendo de um grupo humano que durante séculos vagou de uma região para outra, de um país para outro, de um grupo humano que sofreu na carne o opróbrio de ser privado de uma nacionalidade; não é sem emoção que abordo esse tema.

E o abordo com a consciência de viver em um país que acolheu generosamente imigrantes de todas as partes do mundo, permitindo que aqui refizessem vidas destroçadas e que, desta forma, contribuíssem para o progresso da sociedade como um todo (...).

Nacionalidade não significa tão somente ter um passaporte, nem apenas preencher requisitos legais.

Há, na questão da nacionalidade, uma dimensão emocional, e até espiritual, que não pode ser ignorada.

Privada de sua nacionalidade, a pessoa tem prejudicada a integridade pessoal, a sua capacidade de se realizar como ser humano (...).

Que cada país se transforme, para cada pessoa, em uma nova Canaã, é o grande objetivo que a humanidade deve colocar nesse fim de milênio.

Evidencia-se no trecho parcialmente transcrito, algo surpreendente: Moacyr foi hábil ao abordar um conceito institucional extraído do âmago da ciência jurídica. E o faz com clareza e objetividade. Mais: plenamente afinado com o entendimento das cortes judiciais e dos jurisconsultos, como se tivesse intimidade profissional com a ciência jurídica.

Elogia o país de acolhimento. Ele é a nova Canaã!

Não o faz sem emoção. O menino do Bom Fim lembra das histórias contadas sobre a saga 
dos imigrantes: ele mesmo filho e neto deles.

E rompe com o formalismo legal positivista. A questão não é formal, mas emocional e espiritual e busca a concretização da integridade pessoal e da capacidade de realização do ser humano.

Em outro texto literário, em sentido paralelo, Moacyr refere-se à questão gêmea: a cidadania.

Está incluída em uma coletânea denominada História da Cidadania, com vários autores, assomando Moacyr como escritor. Sua narrativa preenche perfeitamente a concepção jurídica contemporânea do conceito de cidadania. Ele a constrói com uma história de um homem comum, um operário com mulher e filho, mas que repentinamente fica desempregado e passa a ter dificuldades para sustentar sua família e ouve dela constantes reclamações.

Um operário perde o emprego.

Sua mulher e o filho pequeno aguardam que ele consiga um novo emprego. E todas as manhãs sai em busca de trabalho.

Como não consegue emprego, a mulher reclama e briga com o marido: ele passa a se embriagar antes de voltar para casa e o rompimento acaba ocorrendo.

Sai de casa e vira morador de rua. Come em albergues, e em decadência psíquica, esquece o nome da mulher, do filho e o seu próprio nome.

Seria um andarilho pela cidade grande.

De repente, é atropelado e fica estendido no asfalto.

Conta Moacyr:

Ali ficou imóvel, caído sobre o asfalto, as pessoas rodeando-o. 
Cad. Líng. Lit. Hebr., n. 15, p. 110-144, 2017

Curiosamente, não tinha dor; ao contrário, sentia-se leve, quase que como flutuando (...). Alguém se inclinou sobre ele, um policial, e lhe perguntou:

- Como é que está, cidadão? Dá para aguentar, cidadão?

Isso ele não sabia, nem tinha importância.

Agora ele sabia quem era. Era um cidadão. Não tinha nome, mas tinha um título: cidadão.

Ser cidadão era, para ele, o começo de tudo, ou o fim de tudo. Seus olhos se fecharam. Mas seu rosto se abriu num sorriso.

O último sorriso do desconhecido, o primeiro sorriso do cidadão.

A outra face de Moacyr Scliar é a sua conduta humanitária. Um homem público.

Quanto faleceu, um eminente professor me consolou: "Perdemos todos um irmão".

Muito adequado, porque seu último livro, Eu vos abraço milhões, tem seu título extraído do quarto e último movimento da nona sinfonia de Beethoven, que inclui um coral e solistas, utilizando o texto Ode à alegria, de Schiller.

Essa obra suprema junciona e conjuga a música orquestral e vocal, a literatura (a poesia de Schiller) e o direito, porque homenageia os princípios da igualdade e liberdade recém proclamados pela revolução francesa.

Não escapou ao Scliar a invocação de Beethoven: os milhões que devemos abraçar.

Nas milhares de mensagens enviadas para a imprensa por seus leitores, alunos, amigos, professores, uma causou impressão distinta.

Uma professora conta que o seu pai, idoso e deficiente físico cadeirante, morava em um modesto apartamento alugado, propriedade de Moacyr no centro de Porto Alegre.

O problema é que não vinha pagando o aluguel e a imobiliária ameaçava com o despejo.

Ela então ligou para o Moacyr e lhe disse que a única distração do pai era seguir de cadeira de rodas até a janela e observar o movimento da avenida.

E, que pagaria os aluguéis atrasados conforme seus rendimentos diminutos.

Resposta dada pelo Moacyr: "Esquece." 
Era pacifista também por princípio (adotava os versos de Isaías?).

Quando uma lancha vinda da Turquia transportando brinquedos e outros bens para crianças palestinas em Gaza e foi atacada por forças israelenses, Moacyr publicou uma crônica declarando-se totalmente contrário àquele ato bélico. Pior do que um crime, foi um erro escreveu.

Foi criticado pelo oficialismo comunitário. Dias depois o governo israelense pediu desculpas.

No episódio em que um canadense ganhou um valioso prêmio em N. York plagiando seu Max e os felinos. Divulgado o plágio na imprensa americana e brasileira, recebeu um ansioso telefonema daquele autor, indagando se haveria processo judicial contra ele. Moacyr apenas the pediu um exemplar do livro; mais tarde foi adaptado para o cinema, com muitos prêmios (que seriam devidos ao Scliar).

Sua resposta ao telefonema, além do pedido do livro: "Não pretendo processar. Não sou belicista".

Era disponível e acolhedor. Aos jovens escritores jamais recusou conselhos. Aos adolescentes e alunos, levava sua palavra nas escolas modestas, situadas nos bairros da periferia em cidades distantes.

Como se fosse uma conclusão:

Esse era - como ele se definia -, o guri do Bom Fim que escrevia.

Moacyr Scliar, autodeclarado:

médico por profissão, escritor por ofício.

Um humanista, idealista e otimista em relação à espécie humana, ao mundo e ao seu país. 
Cad. Líng. Lit. Hebr., n. 15, p. 110-144, 2017 


\section{Referências}

ALTAVILA, Jayme. Origem dos direitos dos povos. 5. ed. São Paulo : Ícone, 1989.

BELKIN, Samuel. A filosofia do Talmud. São Paulo : Exodus/Sêfer, 2003.

BÍBLIA sagrada. Rio de Janeiro : Sociedade bíblica do Brasil, s/d.

BLOOM, Harold. Jesus e Javé: os nomes divinos. Rio de Janeiro : Objetiva, 2006.

BOBBIO, Norberto. A era dos direitos. Rio de Janeiro : Campus, 1992.

COMPARATO. Fábio Konder. A afirmação histórica dos direitos humanos. 2. ed. São Paulo : Saraiva, 2001.

CRÜSEMANN, Frank. A Torá. Petrópolis : Vozes, 2001.

DONINI, Ambrogio. Breve história das religiões. Rio de Janeiro : Civilização Brasileira, 1965.

GLISSEN, Introdução história ao Direito. Lisboa : Fundação Calouste Gulbenkian, 2001.

GIORDANI, Mário Curtis. Direito romano. Rio de Janeiro : Lumen Juris, 1991.

GOLDMAN, Lucien. Dialética e Cultura. Rio de Janeiro : Paz e Terra, 1967.

JOSEFO, Flávio. História dos Hebreus, Obra completa. Rio de Janeiro : CPAD, 1990.

MARX, Karl. A questão judaica. 2. ed. São Paulo : Moraes, 1991.

O TALMUD. Tradução, estudos e notas de Moacir Amâncio. São Paulo : Iluminuras, 2000.

SCLIAR, Moacyr. O exército de um homem só. São Paulo : L\&PM Editores, 1997

2006.

A escrita de um homem só. / Moacyr Scliar. Porto Alegre : Instituto Estadual do Livro,

Os vendilhões do templo. São Paulo : Companhia das Letras, 2006.

Manual da paixão solitária. São Paulo : Companhia das Letras, 2008.

A mulher que escreveu a Bíblia. São Paulo : Companhia das Letras, 2009. 
Cad. Líng. Lit. Hebr., n. 15, p. 110-144, 2017

Judaísmo - dispersão e unidade. São Paulo : Editora Ática, 2001.

Terras Prometidas - imagens da natureza e do trabalho nas literaturas judaica e brasileira. Porto Alegre : L\&PM Ed., 1997.

A condição judaica - das tábuas da lei à mesa da cozinha. Porto Alegre : L\&PM Editores, 1985.

O nascimento de um cidadão. In: PINKY, Jayme (Org.). História da cidadania. São Paulo : Contexto, 2003.

Cidadania. Direitos Humanos no cotidiano. Brasília : UNESCO; USP: Governo Federal.

2000.

A nossa frágil condição humana - crônicas judaicas. (Org. Regina Zilberman). São Paulo : Cia das Letras, 2017.

Caminhos da esperança - a presença judaica no Rio Grande do Sul. Porto Alegre : Inst. Cultural Marc Chagall, s/d.

SCLIAR, Wremyr. Moacyr Scliar, literatura e humanismo. In: BERND, Zilá e outros. (Org). Tributo a Moacyr Scliar. Porto Alegre : Edipuc,2012.

maio/ago, 1992.

A lei e a justiça no Velho Testamento. Rev. Estudos Jurídicos, v.25, n. 64, p. 51, TOURAINE, Alain. O que é democracia. 2. ed. Petrópolis : Vozes, 1996.

ZERO HORA, Porto Alegre. 23 ago. 2003. 